\title{
The Influence of Cognitive Learning Style and Learning Independence on the Students' Learning Outcomes
}

\author{
Prayekti \\ Lecturer of Educational Physics, Indonesia \\ Correspondence: Prayekti, Lecturer of Educational Physics, Indonesia. E-mail: prayekti@ecampus.ut.ac.id
}

Received: March 10, 2018

Accepted: March 23, $2018 \quad$ Online Published: April 6, 2018

doi:10.5539/hes.v8n2p37

URL: https://doi.org/10.5539/hes.v8n2p37

\begin{abstract}
Students of Open University are strongly required to be able to study independently. They rely heavily on the cognitive learning styles that they have in attempt to get maximum scores in every final exam. The participants of this research were students in the Physics Education program taking Thermodynamic subject course. The research analysis employed a two-way ANOVA statistical analysis with the following findings. First, the significance value of the students' cognitive learning styles variable equals to $0,000<\alpha=5 \%$, so it was concluded that the students' cognitive learning styles strongly influenced their learning outcomes in Thermodynamic Science course manifested in the form of either dependent or independent cognitive styles. Second, the students' learning independence variable turned out to be not having any significant relationship with the students' learning outcomes in Thermodynamic. The learning independence variable had no significant influence on the students' learning outcomes with the level of significance of dependent cognitive style $0.007<\alpha=5 \%$, so it was concluded that the dependent cognitive learning style influenced the learning outcomes, and the learning independence as well as cognitive learning styles, especially the dependent type, altogether influenced the students' learning outcomes in Thermodynamic. The learning independence variable significantly had no influence on the learning outcomes, with $0.007<\alpha=5 \%$ meaning that the dependent cognitive learning style strongly influenced the learning outcomes.
\end{abstract}

Keywords: cognitive style, independent, dependent, learning independence, learning outcomes

\section{Introduction}

Independence is one of many personal aspects which is very important for every individual in living their lives, which can never be separated from trials and challenges. Individuals who have a high level of independence are relatively able to deal with any kinds of problems because independent individuals are not dependent on others as they always try to encounter and solve the existing problems themselves. According to Mungin Edy Wibowo (2002: 69) independence refers to the level of development of an individual by being able to stand by his own feet and rely on his own ability in completing various kinds of activities as well as and solving various problems encountered. Any individuals in this life can never be separated from trials and challenges. Individuals who have a high level of independence are relatively able to encounter any kinds of problems because an independent individual does not rely on others, but always tries to encounter and solve any existing problems. Independence is defined as the situation in which an individual is willing to and able to manifest his own will or desire in the form of actions or real efforts to produce something (either goods or services) for the sake of fulfilling his and others' needs. From the above opinions, it can be concluded that independence is someone's ability in manifesting his willingness or desire into reality by not depending on other people. Therefore, the term independence in this research study refers to the students' behaviors in manifesting his willingness or desire into reality by not depending on others, in this case the students are said to be able to complete self-study activities, determine corresponding learning styles appropriately and complete learning activities independently.

Learning is a process by which an individual undertakes to gain a whole new behavioral change, as a result of the individual's own experience in his interaction with his environment. Meanwhile, Moeslichatoen (2004) states that learning can be defined as a process that contains the learning process and change itself resulting from the effort in undergoing the process. Next, Hilgard \& Blower (in Hamalik, 2004: 45) remark that learning is the change of behaviors through activities, practices, and experiences. In learning, there are some basic components involved: a) learning allows changes to take place (such as intended behavioral changes, either actual or 
potential); b) the changes result in new skills; c) the changes occur because of efforts (Suryabrata, 2001: 232). According to Cronbach in his book Educational Psychology (Suryabrata 2012: 231), "learning is a change in organism due to experience which can affect the organism's behavior". In a similar vein, Hintzman (in Syah 2006: 65), a change that occurs due to a new experience can be said as a result of learning if it affects the organism. From the above experts' opinions, it can be concluded that learning is a process that is undergone by an individual that makes him from the state of not knowing to the state of knowing and it involves the psychological element of the individual.

Cognitive style is a learning condition variable that becomes one of many factors to consider in designing a lesson plan. Knowledge about cognitive styles is needed in designing or modifying learning materials, objectives, and methods. It is expected that by the presence of interaction between students' cognitive styles and the learning materials, objectives, and methods maximum learning outcomes will be achieved by the students. This is in compliance with the opinions stated by some education experts that certain learning strategies require certain learning styles. Cognitive style refers to the cognitive process of an individual in relation to the understanding, knowledge, perception, thought, imagination, and problem solving. Cognitive style is an individual's characteristic in thinking, feeling, memorizing, solving problem, and making decision. Information that is neatly and systematically arranged can easily be absorbed by some individuals. Meanwhile, some other individuals can easily absorb information that is not quite neatly and systematically arranged. As a behavioral characteristic, cognitive style is categorized in the area of skill and personality which is manifested in several activities and media. Cognitive style shows the presence of variations between individuals in their attempt to approach a certain task, but this variation does not represent any particular level of intelligence or ability. As a behavioral characteristic, the same characteristic of two individuals who have the same cognitive style may have different abilities, moreover if there are individuals with different cognitive styles the possibility of having different abilities is higher.

Every individual has a different style in processing information. Therefore, cognitive styles are the steps taken by individuals in processing information through responsive strategies on the assigned task. In regard to this, Woolfolk (1993) shows that in understanding cognitive style there are different ways of seeing, recognizing, and organizing information. Every individual will select his preferred way of processing and organizing as in response to the stimulation given by the environment. There are individuals who are fast and slow in responding. These ways of responding are also related to personal behavior and quality, and an individual's cognitive style represents individual variations in giving attention, processing information, remembering, thinking which appear and make difference between cognition and personality. Furthermore, cognitive style is a pattern formed by the way an individual processes information, which tend to be stable although not necessarily unchangeable.

Generally, cognitive style is obtained and formed in a long period of time as a continum. The widely selected differentiation is based on the psychological aspect, namely field independence (FI) and field dependence (FD). As one of the students' characteristics, the position of cognitive style in the learning process is vital to be paid attention to by the teachers or lesson planner because lesson plans which are designed and arranged by taking into account the factor of cognitive style means providing learning instructions that are suitable with the characteristics and potentials that the students have. With this kind of plan, the learning condition will be created much better because the kind of learning does not interfere with the students' rights. In addition, the learning is adjusted with the students' cognitive process and development.

Activation of the cognitive process is closely related to the characteristics of the student's cognitive process. Thus, improving the cognitive processes of the students strongly requires the attention on the characteristics of each individual student. In lesson plans using elaboration model and textbook organization, before the plans are arranged, the first thing that the teacher needs to do is conducting tests on the students' characteristics which are directed to the test of cognitive styles identification. A student who has the cognitive style of FD, which leads to the global perceptual style, feels the heavy and difficult burden in processing information but is easy to have perceptions if the information is manipulated according to the context. Meanwhile, an individual who has a psychological difference of FI, which leads to articulation, will have analytical perceptions by separating the stimuli from the context, but the perception level is low when there is a change in the context. However, a psychological difference can be changed through the exposure of various situations. Individuals categorized as FI usually use internal factors as the direction of processing information. People with FI prefer to complete tasks unsystematically and feel that it is more efficient to work alone than with partners.

Based on that, then as a student of Open University in Indonesia, the students must be able to learn independently using various available sources in various media including the internet and must also be strong, tough, and passionate during their study in the university. Thus, the formulation of the research problem is "How 
is the influence of cognitive style and student learning independence on their learning outcomes?" which is described in several research objectives as follows. (a) How does the student's cognitive style influence their learning outcomes in studying Physics?; (b) How is the influence of learning independence on the learning outcomes of Physics?; (c) How do the cognitive style and learning independence influence the students' learning outcomes in Physics?; (d) How is the interaction between learning independence, cognitive style and the students' learning outcomes in Physics?.

\section{Literature Review}

The current learning outcomes on Physics subject courses that the students have are still far from expectations, in spite of the fact that there have been many efforts to improve the students' learning achievement in many areas, such as: revising the curricula, providing seminars and workshops for the lecturers, providing supporting learning media and infrastructures, and many others. However, it is a fact that the Physics students' learning outcomes are considered to be low. Based on the researcher's observations and experiences as one of the Physics lecturers in Open University, the statement is considered to be true because in the previous final semester there was only about $65 \%$ who were said to pass the course and graduate with pass/merit results, while the rest of the students failed to pass the course had to retake it in the following semester. This may happen as a result of the students' lack of understanding on the materials of Thermodynamic course. In addition, in the tutorial activities, the lecturers only use the whiteboard as the media and sometimes if the pictures are already available in the textbook, then the lecturers are hesitant to draw it again making the instructional materials hard to understand and the students' motivation and interest low.

Students with high learning independence are expected to (1) learn better under their own supervision than under the program supervision by the university, (2) be able to monitor, evaluate and organize their learning effectively, (3) save time in completing the task, (4) organize learning and time effectively. Based on the research reported in Silmi (2013), which descriptively analyzed the cognitive styles of FD-FI of middle school students on the Physics learning using Levels of Inquiry Model, there was a finding that in general the research sample in the middle school has a balanced total number of students with FD and FI type. The group of students with FD cognitive style was $38.46 \%$, while the group of students with FI cognitive style was $42.31 \%$. The score result of the inquiry ability had by the group of students with FD was 47.37, while the score result of the inquiry ability had by the group of students with FI was 67.12 .

\subsection{Learning Independence}

Self-regulated learning emphasizes autonomy and control by the individual who monitors, directs, and regulates actions toward goals of information acquisition, expanding expertise, and self-improvement". In particular, self-regulated learners are cognizant of their academic strengths and weaknesses, and they have a repertoire of strategies they appropriately apply to tackle the day-to-day challenges of academic tasks. These learners hold incremental beliefs about intelligence (as opposed to entity, or fixed views of intelligence) and attribute their successes or failures to factors (e.g., effort expended on a task, effective use of strategies) within their control. Finally, students who are self-regulated learners believe that opportunities to take on challenging tasks, practice their learning, develop a deep understanding of subject matter, and exert effort will give rise to academic success (Perry et al., 2006). In part, these characteristics may help to explain why self-regulated learners usually exhibit a high sense of self-efficacy. In the educational psychology literature, researchers have linked these characteristics to success in and beyond school

Learning independence can be understood as a characteristic, behavior, and skill had by the students to complete learning activities either by themselves or with some help from other people. This is in line with the statement that learning independence is the ability of the students in putting their willingness or desire into reality without being dependent on others, in this case the students are able to study independently, determine an effective type of learning, and conduct learning activities independently. The role of willingness to be independent is very important in starting and maintaining the students' learning efforts. In learning independence, the control is gradually shifted from the teacher to the student himself. The students have a high level of freedom to determine what kind of lessons and learning objectives that they want to achieve and consider to be beneficial to them (Nursiti, 2012).

According to Thoha (2012), the characteristics of independence include the ability (1) to think critically, creatively and innovatively, (2) not easily be influenced by others' opinions, (3) to not from or avoid problems, (4) to solve the problems by having a deep thought and consideration about it, (5) to solve problems without any help from others when encountering problems, (6) to not feel inferior when being different from others, and (7) to work hard with a good level of diligence and discipline and be responsible for all his actions. In particular, the 
concept of learning independence is characterized by the ability to (1) think critically, creatively, and innovatively, (2) discover the individual's own self-identity, (3) have initiatives in every step of his activities, (4) make considerations and judgments in his actions, (5) be responsible for all he has done, (6) fulfill his own needs and (7) not feeling inferior when required to be different.

Learning independence as proposed by Sitti Fitriana (2015) includes findings that (1) a huge number of students already had certain levels of self-efficacy, learning activity, learning independence, logical thinking, and a medium level of learning outcomes on Physics. Also, (2) the variable that have significant influences is self-efficacy which has a direct influence on the learning outcomes, learning independence, and logical thinking ability. The insignificant influence of self-efficacy is said to be indirectly on the students' learning activities, while self-efficacy has no direct influence on learning outcomes through learning independence. Independence is said to be an important aspect of personality for an individual. Everyone in this life can never live without any trials or challenges that may occur to them. Individuals with a high level of independence are relatively able to encounter and solve any problems because an independent individual never relies on others and always tries to encounter and solve any problems without expecting for help from other people. Based on the above explanations, it can be concluded that the characteristics of learning independence of every student may occur if the students have shown changes in learning in attempt to be independently responsible for his own task. The characteristics of learning independence cover the ability to work by himself, to be responsible for all his actions, to work hard, to solve any problems encountered, to be self-confident and to appreciate time.

\subsection{Field Dependent and Field Independent Cognitive Styles}

Every individual has different characteristics, and the characteristics are not owned by any other individuals. Therefore, it can be said that every individual is different from one another. In addition to that, every individual is different from one another on the ability of solving problems, the intelligence level, and the ability to think, in particular students are different in the way they obtain information, store it, as well as apply knowledge. Among the students, there are also differences in their approach on various learning situations in receiving, organizing and connecting experiences in responding to certain teaching methods. The differences between individuals that exist in arranging and processing information as well as experiences are known as cognitive styles (Slameto, 2010). Cognitive style refers to the way people process, store or even use information in response to certain tasks or various situations in the surrounding environment. It is categorized as a style instead of a skill or an ability because it deals with how an individual processes information and solves problems instead of dealing with how to provide the best solution of a problem. There are several definitions of the term cognitive style proposed by some experts, but the main principle of them stays the same. Cognitive style is best defined as the typical ways used by individuals to build or mold their beliefs and attitudes about the world around them and how to process and react to the information that enters or received by the individual.

Witkin \& Moore (in Mallala, 2003: 16) state that in every learning activity every individual can be categorized into two domains: global and analytic. Individuals with global characteristics are those who prefer to receive things using a global perspective and find difficulties to separate himself from the surrounding environment or it can be said that they are easily influenced by the environment. Individuals with those characteristics are said to have Field Dependent (FD) cognitive style. Meanwhile, Individuals with analytical characteristics are individuals who tend to explain things by providing loose descriptions drawn from the settings, and are also able to differentiate objects from the surrounding context. They see the surrounding environment with an analytical approach. Individuals with these characteristics are said to have Field Independent (FI) cognitive style. This type of an individual is able to cope with the effects from the distracting background elements when he tries to differentiate the relevance aspect of particular situations. The more independent a person is, the more analytical the person on the distracting factors. Individuals who can operate their learning analytically are called field independent (FI) and those who can operate their learning globally are called field dependent (FD). Based on the above explanations, Witkin (in Mallala, 2003: 16) differentiates cognitive styles into two types, they are (a) FI, individuals who can overcome the effects of distractors using analytical perspectives and (b) FD, individuals who can overcome the effects of distractors using global perspectives. The characteristics of individuals with FD and FI are as follows: (1) In completing tasks or solving problems, an FI individual will work best when given a certain degree of freedom, while an FD individual will work best when given an extra degree of directions or guidance; (2) An FI individual has a certain tendency to not easily be influenced by the environment, while an FD individual has a certain tendency to easily be influenced by the environment; (c) In completing tasks or solving problems which require certain skills, an FI individual will show a better result than an FD individual.

Meanwhile, the FD type of cognitive style of a person in responding to information or completing tasks received cannot directly be responded or answered, instead they need a certain degree of encouragement or discussion 
from friends or his surrounding in attempt to answer or respond to the tasks because for them the presence of others is a significant factor.

In particular, Thermodynamic Science is a subject course that is considered to be quite hard to learn independently either individually or in groups. This is because this subject course needs many opportunities to conduct practicum to prove the validity of theories or laws. Therefore, the students need to have full concentration and focus in learning Thermodynamic Science. When the final exam of the semester came previously, most of the students did not realize this that was why there were many students who did not pass the subject course and had to retake the course in the following semester. This is one reason why this research employs the Thermodynamic Science subject course in this study.

\section{Research Methods}

The population of students majoring in Physics were as many as 127 students from different regions in the country. Thus, the first step was to make questionnaires to the students who participated in the course's online tutorials. The second step was to distribute the questionnaires through mail posts and direct visitations to the students who were still reachable. The sample of this study consisted of the students who took Thermodynamic Science course from different UPBJJ-UT (regional branches of the Open University) form Yogyakarta, Semarang, and Purwokerto.

This research design was considered to be explorative, which attempts to explore particular conditions or situations of the research subjects. It also investigates whether the variables included in this research have significant contributions one another between the independent variables (learning independence and cognitive learning styles) and dependent variable (students' learning outcomes). The assumptions of this research were: (1) There was a significant influence between cognitive styles and the students' score results in Thermodynamic Science Final Exam, (2) There was a significant influence between learning independence and the students' score results in Thermodynamic Science Final Exam, (3) There was a significant influence between cognitive styles and learning independence altogether and the students' score results in Thermodynamic Science Final Exam, (4) There was a significant interaction between the students' cognitive styles and their learning independence and the students' score results in Thermodynamic Science Final Exam. In this research, the steps to complete the research included employing the research following research instruments. Firstly, the questionnaires which were already answered by the students which contained information about the students' cognitive styles and readiness to embrace learning independence. Secondly, the students' score results in Thermodynamic Final Exam taken from Exam Score List provided by the university for Thermodynamic in 2016.2 and 2017.1 academic year. With the assumption that the students of Physics Education have not yet experienced any significant changes in learning and that they still use the same learning instructions and instructional materials.

\subsection{Research Instruments}

To investigate the cognitive styles of the students, The Embedded Figures Test (EFT) proposed by Witkin (1977) was used. It was a perceptual test using figures or pictures. It employs outer frame references substituted by complex pictures, with simple pictures hidden behind the complex ones. As for the learning independence, a questionnaire proposed by Tri Darmayanti was used. It consisted of 32 questions that need to be answered by the students.

\section{Findings and Discussion}

This research was analyzed using two-way ANOVA research analysis. The two-way ANOVA is also called ANOVA bivariate (two variance) analysis. It compares the average differences between the groups which have been clustered into two independent variables (called factors). Two independent variables are needed which are categorical data and one bound or dependent variable with numerical or quantitative data scale (interval or ratio). ANOVA stands for "analysis of variance" which is one kind of comparative test used for testing the mean difference of data of two different groups. There are two kinds of ANOVA, namely one-way ANOVA (one factor variance analysis) and two-way ANOVA (two factors variance analysis). In utilizing ANOVA measurement test, there should be several assumptions to be fulfilled, they are: (1) the sample should be from an independent group; (2) the variance across the groups should be homogenous; (3) the residual value should have a normal distribution trend. Principally, the two-way ANOVA is used on the same group sample. Thus, it can be concluded that (1) seen from the purpose, it is to compare the means or average values of two or more groups; (2) The sample used should have been categorized in the same group; (3) In every group there should be test repetitions by combining one-way ANOVA and two-way ANOVA without including any interaction between them. The assumptions that must be met in the analysis of variance (ANOVA) are that: (1) the data is normally distributed, because the test uses the F-Snedecor test; (2) The variants or varieties are homogeneous, known as 
homoscedasticity, since there is only one estimation used for the variance in the example; (3) Each of the examples should be independent, which should be subject to the proper design of the experiment; (4) The components in the model are additive. From a total population of 127, the researchers successfully collected the data from respondents as many as 78 who took the Thermodynamic Science course at the time of registration of 2016.2 and 2017.1.

Apart from the three Regional Center locations mentioned previously used as the sample, there were also some other Regional Center locations which have a lot of Physics Education students, they are Pontianak, Surabaya, Jember, and Surakarta. The data collection required the researcher to contact her colleagues who are in the close proximity with the locations to gather the students and conduct data collection activities. Next, the data was then analyzed in order to obtain the independent and dependent cognitive style classifications by calculating the mean and the values greater than the mean to be considered as independent cognitive style and the mean and values smaller than the mean to be considered as dependent cognitive style. Next, the data was processed using double regression analysis using the SPSS program in order to investigate the relationship between independent cognitive style, dependent cognitive style, the high level of learning independence group and the low level of learning independence group.

\subsection{Regression Analysis (Learning Independence and Cognitive Style on the Students' Final Exam/Learning Outcomes)}

This study employed regression analysis method to determine whether there is any influence between the learning independence variable and cognitive styles on the students' learning outcomes. After the data processing was conducted, the following results were obtained.

A. F- test

ANOVA

\begin{tabular}{llllll}
\hline Model & Sum of Squares & df & Mean Square & F & Sig. \\
\hline Regression & 2466,654 & 2 & 1233,327 & 21,816 &, $000^{\mathrm{b}}$ \\
Residual & 4239,989 & 75 & 56,533 & & \\
Total & 6706,643 & 77 & & & \\
\hline
\end{tabular}

a. Dependent Variable: Final_Exam_Scores

b. Predictors: (constant) Cognitive_styles, Learning_Independence

Based on the above output, the obtained value of significance level was sig $=0.000$. This value is smaller than $\alpha$ $=5 \%$, so it was concluded that the model fits and matches (between learning independence and cognitive styles altogether and the students' learning outcomes). In order to investigate further what kind of variable that was individually influential, a t-test (parameter significance test) was then conducted.

B. t-test (parameter significance test)

Coefficients $^{\mathrm{a}}$

\begin{tabular}{|c|c|c|c|c|c|c|c|}
\hline \multirow[t]{2}{*}{ Model } & \multicolumn{2}{|c|}{$\begin{array}{l}\text { Unstandardized } \\
\text { Coefficients }\end{array}$} & \multirow{2}{*}{\begin{tabular}{|l|} 
Standardized \\
Coefficients \\
Beta
\end{tabular}} & \multirow[t]{2}{*}{$\mathbf{t}$} & \multirow[t]{2}{*}{ Sig. } & \multicolumn{2}{|c|}{$\begin{array}{l}\text { Collinearity } \\
\text { Statistics }\end{array}$} \\
\hline & B & Std. Error & & & & Tolerance & VIF \\
\hline (Const & 5,811 & 12,779 & & 4,455 & ,651 & & \\
\hline Learning_Independence & ,139 & ,104 & ,127 & 1,342 &, 184 & ,943 & 1,060 \\
\hline Cognitive_Styles & 818 & ,137 & ,564 & 5,963 &, 000 & ,943 & 1,060 \\
\hline
\end{tabular}

a. Dependent Variable: Final_Exam_Scores

Based on the above output, the significance value of the learning independence variable was $0.184>\alpha=5 \%$ so it can be concluded that significantly the learning independence variable had no influence on the learning outcomes, while the significance value of cognitive styles variable was $0.000<\alpha=5 \%$ so it can be concluded that cognitive styles variable strongly influenced the learning outcomes.

4.1.1 Regression Analysis I (Learning Independence and Dependent Cognitive Styles on the Final Exam Scores/Learning Outcomes)

A. F-test 
ANOVA $^{\mathrm{a}}$

\begin{tabular}{lllll}
\hline Sum of Squares & df & Mean Square & F & Sig. \\
\hline 474,371 & 2 & 237,185 & 4,438 &, $021^{\mathrm{b}}$ \\
1549,826 & 29 & 53,442 & & \\
2024,196 & 31 & & & \\
\hline
\end{tabular}

a. Dependent Variable: Final_Exam_Score

b. Predictors: (Constant), Cognitive_dependent, learning_independence

Based on the above output, the obtained significance value was 0.021 . This value was smaller than $\alpha=5 \%$ or $00.21<\alpha=5 \%$, so it can be concluded that the model was fit (learning independence and dependent cognitive style variables altogether have significant influence on the students' learning outcomes). In order to further investigate which variable that can individually influence the learning outcomes, then the following t-test was also conducted.

B. t-test

Coefficients $^{\mathrm{a}}$

\begin{tabular}{|c|c|c|c|c|c|c|c|}
\hline \multirow[t]{2}{*}{ Model } & \multicolumn{2}{|c|}{$\begin{array}{l}\text { Unstandardized } \\
\text { Coefficients }\end{array}$} & \multirow{2}{*}{$\begin{array}{l}\text { Standardized } \\
\text { Coefficients } \\
\text { Beta } \\
\end{array}$} & \multirow[t]{2}{*}{$\mathbf{t}$} & \multirow[t]{2}{*}{ Sig. } & \multicolumn{2}{|c|}{$\begin{array}{l}\text { Collinearity } \\
\text { Statistics }\end{array}$} \\
\hline & B & Std. Error & & & & Tolerance & VIF \\
\hline (Const & 28,949 & 16,456 & & 1,759 & 089 & & \\
\hline Learning_indep &,- 066 & ,139 &,- 082 &,- 474 & 639 & ,891 & 1,123 \\
\hline Cognitive_dependent & 1,089 & ,371 &, 505 & 2,933 & ,007 &, 891 & 1,123 \\
\hline
\end{tabular}

a. Dependent Variable: Final_Exam_Score

Based on the above output, the obtained significance value was $0.639>\alpha=5 \%$, so it can be concluded that significantly the learning independence variable had no influence on the students' learning outcomes, while the obtained significance value for dependent cognitive styles variable was $0.007<\alpha=5 \%$, which means that the dependent cognitive learning style strongly influenced the students' learning outcomes.

4.1.2 Regression Analysis II (Learning Independence and Independent Cognitive Style on the Final Exam Scores/Learning Outcomes)

A. F-test

ANOVA $^{\mathrm{a}}$

\begin{tabular}{lccccc}
\hline Model & Sum of Squares & df & Mean Square & F & Sig. \\
\hline Regression & 975,476 & 2 & 487,738 & 9,543 &, $000^{b}$ \\
Residual & 2197,678 & 43 & 51,109 & & \\
Total & 3173,154 & 45 & & & \\
\hline
\end{tabular}

a. Dependent Variable: Final_Exam_Score

b. Predictors : (constant), Independent_Cognitive_Style, Learning_Independence

Based on the above output, the obtained significance value was 0.000 . This value was smaller than $\alpha=5 \%$, so it can be concluded that the model suitably fits (learning independence and independent cognitive style variables altogether influence the students' learning outcomes). In order to identify which variable that individually influenced the learning outcomes, the following t-test was then conducted

B. t-test

ANOVA $^{\mathrm{a}}$

\begin{tabular}{llllll}
\hline Model & Sum of Squares & df & Means Square & F & Sig. \\
\hline Regression & 975,476 & 2 & 487,738 & 9,543 &, $000^{\mathrm{b}}$ \\
Residual & 2197,678 & 43 & 51,109 & & \\
Total & 3173,154 & 45 & & & \\
& & & & & \\
\hline
\end{tabular}


a. Dependent Variable: Final_Exam_Score

b. Predictors: (Constant), Independent_Cognitive_Style, Learning_Independence

Based on the above output, the obtained significance value was 0.000 . This value was smaller than $\alpha=5 \%$, so it can be concluded that the model suitably fits (learning independence and independent cognitive style variables altogether influence the students' learning outcomes). In order to identify which variable that individually influenced the learning outcomes, the following t-test was then conducted.

C. t-test

\begin{tabular}{llllllll}
\hline Model & \multicolumn{2}{l}{$\begin{array}{l}\text { Unstandardized } \\
\text { Coefficients }\end{array}$} & $\begin{array}{l}\text { Standardized } \\
\text { Coefficients }\end{array}$ & t & Sig. & $\begin{array}{l}\text { Collinearity } \\
\text { Statistics }\end{array}$ \\
\cline { 2 - 8 } & B & Std Error & Beta & & & Tolerance & VIF \\
\hline (Constant) & $-53,382$ & 23,124 & & $-2,309$ &, 026 & & \\
Learning_Independence &, 411 &, 149 &, 350 & 2,753 &, 009 &, 997 & 1,003 \\
Independent_Cognitive_Style & 1,872 &, 531 &, 448 & 3,526 &, 001 &, 997 & 1,003 \\
\hline
\end{tabular}

a. Dependent Variable: Final_Exam_Score

Based on the output above, the obtained significant value of learning independence was $0.009<\alpha=5 \%$, so it can be concluded that the learning independence variable significantly influenced the students' learning outcomes, while the obtained significant value of independent cognitive style was $0.001<\alpha=5 \%$, so it can be concluded that independent cognitive style also influenced the students' learning outcomes.

\section{Interviews}

Based on the interview results with several students regarding answering the questionnaires on cognitive styles especially for the difficulties found when filling in the questionnaires, the following points are noted.

\begin{tabular}{lll}
\hline \multicolumn{1}{c}{ Questions } & Yes (\%) & No (\%) \\
\hline For Part 1 & \multicolumn{2}{c}{} \\
Did you find any difficulties in answering them? & 5 & 95 \\
Did you find any difficulties in blocking the boxes? & 35 & 65 \\
Did you think hard to answer them? & 45 & 55 \\
For Part 2 & & 55 \\
Did you find any difficulties in answering them? & 45 & 35 \\
Did you find any difficulties in blocking the boxes? & 65 & 25 \\
Did you think hard to answer them? & 75 & \\
For Part 3 & & 35 \\
Did you find any difficulties in answering them? & 65 & 25 \\
Did you find any difficulties in blocking the boxes? & 75 & 15 \\
Did you think hard to answer them? & 85 & \\
\hline
\end{tabular}

From the table above, it can be concluded that in answering the cognitive style questionnaires required some time to think before blocking the boxes, and this questionnaire was considered to be quite difficult for the participants. This may be the reason why there was only one participant who returned the questionnaire to the researcher through mail post, due to the fact that it took time for the participants to answer the questionnaire items and they might find difficulties in answering them.

\section{Discussion}

The difficulty of meeting all the 127 students who took the PEFI4208 Thermodynamic course as the respondents is a unique and interesting thing to discuss. At the beginning of the data collection activity, we already used e-mail to send the questionnaires to all the students of the online tutorials and it was only fifteen students who completed the questionnaires and we decided to use mail post services to send the questionnaires to the rest 112 students who previously did not respond to our e-mails. However, there was only 1 person who returned the questionnaire through mail post. Thus, we decided to conduct visitations to the students who took the PEFI4208 Thermodynamic course in several Regional center locations in Yogyakarta, Purwokerto, Pontianak, Jember and 
Surabaya. By doing so we managed to gather about 78 respondents in order to determine their independent/dependent cognitive learning styles based on the value of mean. Values higher than the mean were considered to represent independent cognitive learning style, while values lower than the mean were considered to represent dependent cognitive learning style.

When conducting the data collection, there were many obstacles encountered. One of which was the addresses of the students which evenly spread through regions making it hard to determine which location to meet up. Secondly, the researcher and colleagues had to find ways to meet up with the respondents in areas that we are not familiar with and we are lucky to have some other colleagues to help with this so that we managed to meet up with the respondents in agreed places and time slots. After that, the respondents were handed out the questionnaire to be filled in and with the help of Regional Center in different locations, the data could be collected even by coming directly to some of the respondents' home address. At last, all the data was collected.

If the independent cognitive learning style is related to the students' learning outcomes in Thermodynamic the value turns out to be 2.112. This means that independent cognitive style has insignificant influence on the Thermodynamic final exam scores. This is because of the range value of the independent cognitive style is at the value of between 23 and 25, which considered to be a low range. This finding proves that the cognitive learning styles had by the students of Physics Education of Indonesian Open University is a gift from the Lord GOD Almighty by putting different styles of learning to different human beings. In addition to that, cognitive learning style is also influenced by the students' learning environment as well as their social environment, but this does not affect much on the real cognitive style of any individuals. Physics as part of Science consists of four things, namely content or product, process or method, behavior and technology. In every learning process, usually there is a graduation competency standard for the students which covers behavioral skills, knowledge and skills. The component of content or knowledge in Physics plays a vital role and is very influential to the other components, because having the right knowledge can also grow and practice good scientific behaviors, abilities and skills. According to Dahar (1989), concepts are best considered to be building blocks for the foundation of thinking. When an individual has mastered the concepts, the individual will already have a strong and solid foundation of thinking to support other skills that he has. The importance of concept mastery to support and develop all the students' potentials have to be concerned with at all times especially in the area of learning process, thus the students can achieve an optimal learning outcomes (such as concept mastery). One of many things that needs to consider in learning is the different characteristics of the students in obtaining and processing information delivered and discussed in the learning processes. Every individual has different characteristics, including in the characteristics in their learning process. The students generally show different kinds of responses when being encountered to the same learning situation and condition; some may be enthusiastic with a certain teaching and learning method while some others feel not very enthusiastic. According to Witkin (1977), the different responses expressed by different individuals are related to the different perceptual and intellectual characteristic approaches which make them respond differently to the situation encountered, this difference is what is called as cognitive style. Cognitive style is a bridge between cognition and action which represents someone's personality, and is a process or control style which occurs from the students which is situational and can determine the students' fully aware activities in organizing, arranging, receiving, and distributing information as well as determining the students' behaviors. Therefore, cognitive style can be considered as the way the students do to obtain, process, and execute information in the form of actions or behaviors when the learning process is ongoing and completed by the individual consistently. Cognitive style can be differentiated based on several grouping methods. One of them was conducted by Witkin (1977) who identified and grouped individuals based on the global/analytic continuum characteristics.

An individual with field dependent (FD) cognitive style is a person who thinks globally, readily accepting the existing structure or information, having social orientation, selecting professions that require social skills, and tends to follow the existing objectives and information as well as prioritize external motivation. Meanwhile, an individual with field independent (FI) cognitive style is a person who is able to analyze objects apart from their surrounding environment, organize objects, have impersonal orientation, prefer professions that tend to be individual, and prioritize internal self-motivation from himself. In every learning process, students who tend to have FD cognitive style characteristics tend to focus more on the general picture; only following information that already exists; but can be cooperated well due to his social orientation ability. Meanwhile, an individual with FI cognitive style characteristics will tend to be able to seek more information outside the existing content; able to differentiate one object from the other surrounding objects more easily and tend to be more analytical; and the motivation strongly depends on the internal motivation. The concept mastery between the students who have an FD cognitive style and FI cognitive style with the same learning, which is Thermodynamic, requires all the 
students to conduct experiments in groups and discuss the results of the experiments with one another in attempt to understand the concepts of Thermodynamic Science.

\section{Conclusions}

1. Significantly, the learning independence variable had no influence on the students' learning outcomes in Thermodynamic Science course, meanwhile the significant value of cognitive style $=0.000<\alpha=5 \%$, it can then be concluded that the students' cognitive style strongly influenced the students learning outcomes in Thermodynamic Science course.

2. Learning independence had no influence on the students' learning outcomes in Thermodynamic Science course, and the field dependent cognitive style value of significance $=0.007<\alpha=5 \%$, meaning that the FD cognitive style strongly influenced the students' learning outcomes in Thermodynamic Science course.

3. The field dependent t-test value was significant at 0.021 which was lower than $\alpha=5 \%$, meaning that the model was already suitable (the learning independence and dependent cognitive style strongly influenced the students' learning outcomes in Thermodynamic Science course).

4. Significantly, the learning independence variable influenced the students' learning outcomes, and the value of significance of the independent cognitive style $=0,001<\alpha=5 \%$, so it can be concluded that independent cognitive style strongly influenced the students' learning outcomes in Thermodynamic Science course.

5. Significantly, the students' learning independence had no influence on the students' learning outcomes in Thermodynamic Science course, and the value of significance of the dependent cognitive style = $0,007<\alpha=5 \%$, so it can be concluded that dependent cognitive style strongly influenced the students' learning outcomes in Thermodynamic Science course.

\section{References}

James, W. Keefe (1087). Learning style: theory and practice. National Association of Secondary School Principals, Education.

Reigeluth, C. M. (1993). Principles of Educational Systems Design. International Journal of Educational

Sitti, Fitriana (2015). Jests Pengaruh Efikasi diri, aktivitas, kemandirian belajar Matematika pada mahasiswa kelas VIII SMP.

Slameto (2010). Belajar dan Faktor-Faktor yang empengaruhinya. Jakarta: Rineka Cipta.

Soedjadi (1986:8 dalam Mallala, 2003:12). mengemukakan tentang gaya kognitif sebagai berikut: "Cognitive style may be described by the following characteristics: They are concerned with the form rather than the content of cognitive activities.

Sumadi, Suryabrata (2012). Metodologi Penelitian, Jakarta: PT. Raja Grafindo Persada.

Syah, Muhibbin (2006). Psikologi Belajar, Jakarta: PT. Raja Grapindo Persada.

Wibowo, Eddy Mungin (2002). Jenis-jenis Layanan Bimbingan dan Konseling. Jakarta: Departemen Pendidikan Nasional.

Witkin (1977:5 dalam Mallala, 2003:17). menyatakan bahwa The Embedded Figures Test (EFT) merupakan tes perseptual yang menggunakan gambar. Rujukan kerangka luar yang disubstitusikan berupa suatu gambar yang rumit, yang menyembunyikan suatu gambar sederhana.

Woolfolk, A. (1993). Educational psychology (5th ed.). Boston, MA: Allyn \& Bacon (643 pp.). http://www.subliyanto.id/2011/05/kemandirian-belajar.html (Abdul Hadis, 2008:60).

\section{Copyrights}

Copyright for this article is retained by the author(s), with first publication rights granted to the journal.

This is an open-access article distributed under the terms and conditions of the Creative Commons Attribution license (http://creativecommons.org/licenses/by/4.0/). 